\title{
Estimation of metal and organochlorine pesticide exposures and potential health threat by consumption of oysters in Taiwan
}

\author{
Bor-Cheng Han ${ }^{\mathrm{a}, *}$, Woei-Lih Jeng ${ }^{\mathrm{b}}$, Tsu-Chang Hung ${ }^{\mathrm{b}}$, Yong-Chien Ling ${ }^{\mathrm{c}}$, \\ Ming-Jer Shieh ${ }^{\mathrm{d}}$, Ling-Chu Chien ${ }^{\text {a }}$ \\ a School of Public Health, Taipei Medical College, 250 Wu-Hsing Street, Taipei, Taiwan \\ ${ }^{\mathrm{b}}$ Institute of Oceanography, National Taiwan University, Taipei, Taiwan \\ ${ }^{c}$ Department of Chemistry, National Tsing Hua University, Hsinchu, Taiwan \\ ${ }^{\mathrm{d}}$ School of Nutrition and Health Sciences, Taipei Medical College, Taipei, Taiwan
}

Received 6 January 1999; accepted 4 August 1999

"Capsule": Human health risk from consuming oysters from 12 areas was determined.

\begin{abstract}
Pollutant concentrations detected in oysters from 12 different culture areas of Taiwan (especially for the Hsiangshan area and the Machu Islands) from 1991-98 were evaluated to investigate potential carcinogenic (inorganic As and organochlorine pesticides) and non-carcinogenic ( $\mathrm{Cu}, \mathrm{Zn}, \mathrm{Cd}$ and inorganic As) risk to the public from ingestion of the oysters. The highest geometric mean (GM) $\mathrm{Cu}$ and $\mathrm{Zn}$ concentrations of 1108 (range 113-2806) and 1567 (range 303-3593) $\mu \mathrm{g} / \mathrm{g}$ dry weight were obtained in oysters from the Hsiangshan coastal area. The maximum GM Cd and As concentrations of 6.82 and $19.3 \mu \mathrm{g} / \mathrm{g}$ dry weight were found in oysters from the Machu Islands area. The $p, p^{\prime}$-DDE values range from not detectable in Penghu Islands' oysters to $164 \mathrm{ng} / \mathrm{g}$ dry weight in Machu Islands' oysters. The highest tDDT (sum of $p, p^{\prime}$-DDE, $p, p^{\prime}$-DDD and $p, p^{\prime}$-DDT) concentrations of 337 and $340 \mathrm{ng} / \mathrm{g}$ dry weight were found in oysters from Kimmen and Machu Islands, respectively. A calculated target hazard quotient (THQ; daily intake/reference dose) of 11.4 (based on $139 \mathrm{~g}$ oysters/day) for $\mathrm{Cu}$ caused by consuming oysters from the Hsiangshan area is higher than that from other areas (range 0.124-5.95). The highest average $\mathrm{Cu}$ intake from Hsiangshan's oysters for individuals is 11.4 times (i.e. THQ = 11.4) more than that of reference dose $(40 \mu \mathrm{g} / \mathrm{kg} / \mathrm{day})$. However, the maximum THQ values for Cd and As caused by consuming oysters collected from the Machu Islands were 5.57 and 2.63 for Cd and As, respectively. Generally, the results of THQ showed that if only the maximally exposed individuals were considered, the value of $65.4 \%$ for oyster was higher than 1.0 in comparison with reference dose. All cancer risk estimates for inorganic As from consuming oysters were higher than $10^{-6}$ (range from $128 \times 10^{-6}$ to $509 \times 10^{-6}$ for maximally exposed individuals and range from $17.1 \times 10^{-6}$ to $68.0 \times 10^{-6}$ for typically exposed individuals, respectively); that is the risk of the lower end of the range of acceptable risk. The highest risk estimate for inorganic As was $509 \times 10^{-6}$ for consumption of oysters by Machu Islands' residents. The lifetime cancer risks of $19.0 \times 10^{-6}$ for tDDT by consuming oysters from the Machu Islands was higher than those from the Penghu Islands $\left(0.37 \times 10^{-6}\right)$. Therefore, the sum of lifetime cancer risks for tDDT and inorganic As had the highest risks (total risk $=528 \times 10^{-6}$ ) of consuming oysters from the Machu Islands. Furthermore, a $10^{-6}$ upper limit on lifetime risk as the health protection standard would require maximum oyster consumption rates of approximately $0.26 \mathrm{~g} /$ day. (C) 2000 Elsevier Science Ltd. All rights reserved.
\end{abstract}

Keywords: Metals; Pesticides; Exposure; Health threat; Oysters

\section{Introduction}

Heavy metals, organochlorine compounds and petroleum hydrocarbons have long been recognized as the most deleterious contaminants to biota in the world's marine and estuarine waters. During the past 20 years

\footnotetext{
* Corresponding author. Tel.: + 886-2-27361661 ext. 666.
}

E-mail addres: bchan@mail.tmc.edu.tw (Bor-Cheng Han). various biomonitoring strategies have been developed to monitor and evaluate the adverse impact of these compounds on marine ecosystems in Taiwan. These projects have become popularly known as the "Mussel Watch" (Hung et al., 1983; UNEP, 1993). Recently, the Mussel Watch program has been expanded into the Asia/Pacific region by International Mussel Watch Committee (IMC), under the support of the United Nations University (UNU, 1994). Scientists from 12 Asia/Pacific 
countries and territories including Taiwan were invited to join the program.

From August 1995 to July 1998, we carried out a 3year Asia/Pacific Mussel Watch (APMW) project with the support of the National Science Council, Republic of China (Han et al., 1998; Hung et al., 1998). For example, the maximum $\mathrm{Cu}$ and $\mathrm{Zn}$ geometric mean (GM) concentrations ( $\mathrm{GM}=229$ and $783 \mu \mathrm{g} / \mathrm{g}$ dry wt, respectively) in oysters (Crassostrea gigas) from different culture areas are much higher than those of the other organisms by about 1.13-458 and 2.40-63.7 times, respectively. In addition, $\mathrm{Cu}$ concentrations in the oysters from the Erhjin Chi estuary declined from $2194 \mu \mathrm{g} / \mathrm{g}$ dry weight in 1986-90 to $545 \mu \mathrm{g} / \mathrm{g}$ dry weight in 1991-96 (Han et al., 1994). In the Hsiangshan area, the GM Cu concentrations of 909 (1991-96) and $1351 \mu \mathrm{g} / \mathrm{g}(1997-98)$ in oysters were significantly higher than those of $201(1980-85)$ and $682 \mu \mathrm{g} / \mathrm{g}$ (1986-1990). The gradually increasing levels of $\mathrm{Cu}$ in the oysters from the Hsiangshan area have been observed year by year (Han et al., 1994, 1998).

Hung et al. (1997) reported that the concentrations of $p, p^{\prime}$-DDE, $p, p^{\prime}$-DDD and $p, p^{\prime}$-DDT in mussels/bivalves from different culture areas varied with species and sampling locations. For instance, the highest $p, p^{\prime}$-DDE average concentrations of $164 \mathrm{ng} / \mathrm{g}$ dry weight were found in oysters from the Machu Islands. Besides, maximum $p, p^{\prime}$-DDD and $p, p^{\prime}$-DDT concentrations (139 and $130 \mathrm{ng} / \mathrm{g}$ dry wt, respectively) were observed in oysters from the Kimmen Islands (Hung et al., 1997).

People can be exposed to toxic chemicals that accumulate in fish and shellfish taken from contaminated waters that are consumed (Han et al., 1994; Svensson et al., 1995). For example, Han et al. (1994) reported the $\mathrm{Cu}$ intake and health threat by consuming seafood from $\mathrm{Cu}$-contaminated coastal environments (Erhjin Chi estuary) in Taiwan. The estimate by Han et al. (1994) indicates that the average $\mathrm{Cu}$ intake from contaminated green oysters for female individuals is 14 times more than that of international limits. Ling et al. (1994) reported that based on an average daily fish consumption of $15 \mathrm{~g}$ for an adult with $70 \mathrm{~kg}$ body weight, a daily intake of PCDD/PCDFs of $8-447 \mathrm{pg} / \mathrm{kg}$ is estimated when consuming fish was from the Erhjin Chi river of Taiwan. The consumption of these contaminated fish will exceed the risk-based concentration of "zero" recommended by the US EPA (1998). People consuming large amounts of contaminated seafood may have elevated concentrations of pollutants in their tissues compared to the general population (Asplund et al., 1994; Dewailly et al., 1994).

However, the possible association between seafood consumption and human exposure to many of these contaminants has not been extensively investigated. The potential risk of consuming oysters is relatively higher than that of other seafood due to the high bioaccumulation of oysters. These high concentrations of $\mathrm{Cu}$ and $\mathrm{Zn}$ may not affect oysters directly (Han and Hung, 1990), but high concentrations of $\mathrm{Cu}, \mathrm{Zn}$, As and organochlorine pesticides may transfer toxicity to humans through the food chain. Based on the above data, we think these calculated data of $\mathrm{Cu}, \mathrm{Zn}$, As and organochlorine pesticide concentrations of Taiwanese diets to be the important information related to health risk for the inhabitants of Taiwan.

The study includes an evaluation of the public health risks associated with various oysters from different culture areas, especially for Hsiangshan, Machu and Kimmen Islands areas. In other words, this study also estimates target hazard quotients (THQs) for metals and lifetime cancer risks for inorganic As and organochlorine pesticides from consuming oysters.

\section{Materials and methods}

The oyster samples were collected from the different coasts of Taiwan during the period from August 1991 to July 1998. Sampling locations are shown in Fig. 1.

The samples were returned to the laboratory, individually scrubbed, and shucked, and the flesh was placed in weighed acid-washed Teflon beakers for reweighing to obtain individual wet-weight values. In general, 1520 individual oysters of similar size $(3.21 \pm 0.40 \mathrm{~cm}$ in shell length) were sampled from each location (Han et al., 1994). The sampling locations were generally in the mariculture area in order to have enough organisms for analysis. All samples were digested using a microwave digester (Model MDS-2000) with a mixture of nitric and sulfuric acids $(1 / 1, \mathrm{v} / \mathrm{v})$ solution, and the supernatant analyzed for $\mathrm{Cu}$ and $\mathrm{Zn}$ by flame atomic absorption spectrophotometry (Han and Hung, 1990). Cd and As were measured by graphite atomic absorption spectrometry using nickel (for As) as matrix modifier, and standard addition procedures were used for the calculation of the analyte concentrations (Han et al., 1997). All data are concentrations $(\mu \mathrm{g} / \mathrm{g})$ on the basis of dry weight by using wet weight $\cong$ dry weight $\times 5$ (Han and Hung, 1990; Han et al., 1994). Determination of metals was performed with a Hitachi Zeeman AAS (model Z-8000 with an autosampler). The results generated were, in most cases, in good agreement with certified values. Standard reference materials (SRM 1566a Oyster Tissue and IAEA 350 Tuna Fish Tissue) were analyzed at regular intervals (Han et al., 1996, 1997, 1998). The precision and accuracy of the analyses have been detailed elsewhere (Han et al., 1997).

The chosen analytical procedures of organochlorine pesticides used in this study were developed in-house and were validated and published in prestigious journals (Chen and Ling, 1994; Ling et al., 1994; Ling and Huang, 1995; Ling and Liao, 1996). The matrix solid phase dispersion (MSPD) extraction gas chromatography-mass 


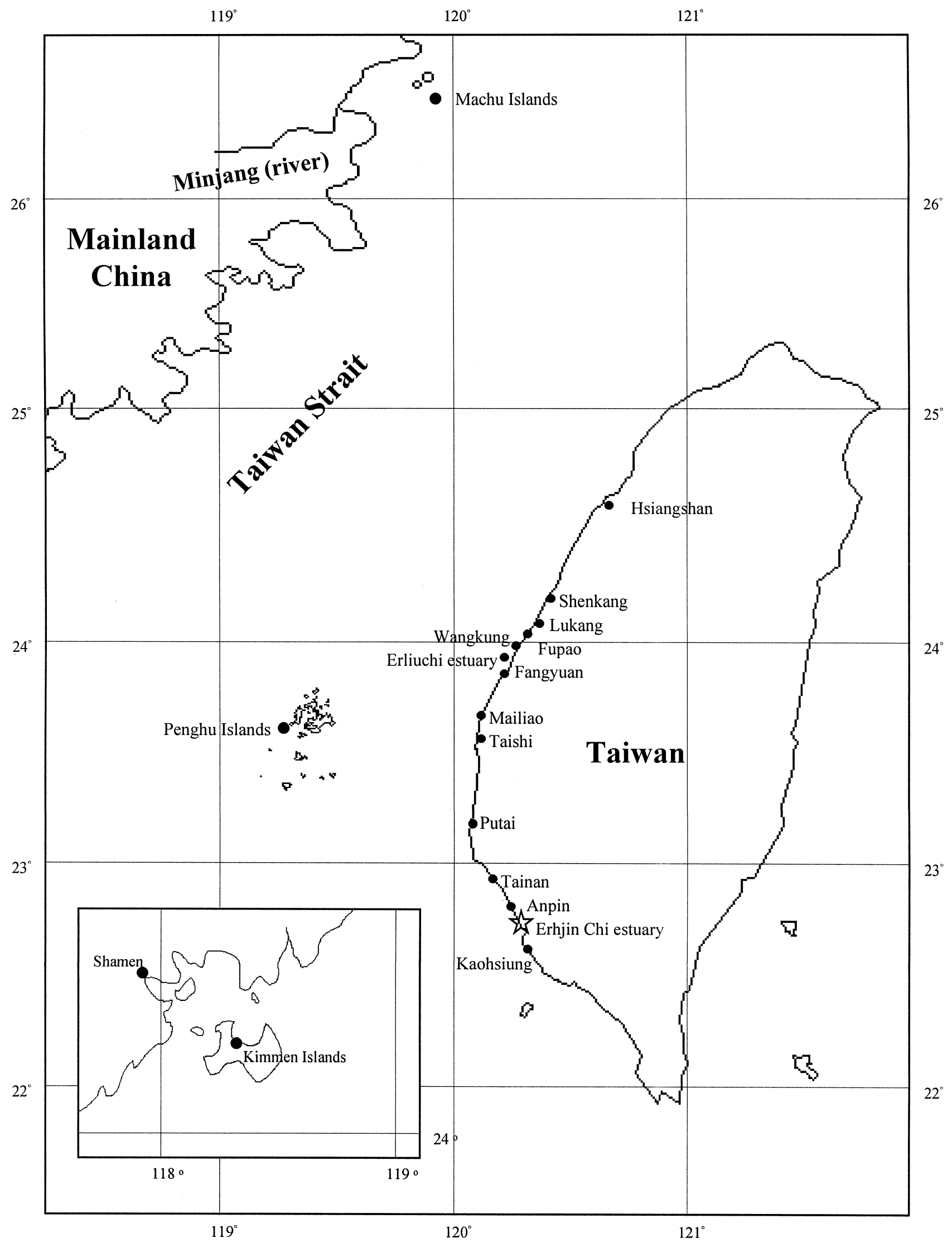

Fig. 1. Sampling locations ( ) of oysters collected from different coastal areas in Taiwan. 
spectrometry (GC-MS) method was used for the confirmatory determination of three organochlorine pesticides ( $p, p^{\prime}$-DDE, $p, p^{\prime}$-DDD, $p, p^{\prime}$-DDT) by level of chlorination in mussels/bivalves. The method uses an octadecylsilyl-derivatized silica and Florisil-based MSPD co-column for direct in-line clean up by using n-hexane-acetone (9:1) as the eluent (Ling and Huang, 1995). Dibromo-octafluorobiphenyl (50 $\mu 1,4 \mathrm{ppm})$ was added as internal standard. The determination of recovery was by GC-electron capture detection (ECD). Correlation coefficients for the calibration curves of each analyte are greater than 0.995 (Hung et al., 1997). The recoveries for $p, p^{\prime}$-DDE, $p, p^{\prime}$-DDD and $p, p^{\prime}$-DDT are $87 \pm 6,81 \pm 9$, and $108 \pm 14 \%$, respectively. The method detection limits varied from 19.6 to $91.1 \mu \mathrm{g} / \mathrm{g}$, which was below the US FDA action levels (Ling and Huang, 1995).

Eight hundred and fifty residents from Taipei City were interviewed. A brief questionnaire was filled in with demographic information and data on nutritional habits. The interview questionnaire included detailed questions about various seafood consumption pertaining to amount and frequency of consumption as well as seafood preparation methods and weeks of consumption. The personal, dietary and residential information included in this study were obtained (Han et al., 1998).

The methodology for estimation of THQs and target cancer risk (TR) used was provided in "US EPA Region III Risk-Based Concentration Table" (US EPA, 1998). For carcinogenic effects, risk is expressed as excess probability of contracting cancer over a lifetime (70year). For non-carcinogenic effects, risk is expressed as a THQ, the ratio between the exposure and the reference dose. According to the report of US EPA (1998), the dose calculations were made using the standard assumption for an integrated US EPA risk analysis, including exposure over an entire 70-year lifetime and to a $65-\mathrm{kg}$ body weight for an average Taiwanese adult. In addition, it was assumed in accordance with the US EPA guidance (US EPA, 1989) that the ingested dose is equal to the absorbed contaminant dose and that cooking has no effect on the contaminants (Cooper et al., 1991).

For statistical analyses, left-skewed data were normalized by logarithmic transformation. Accordingly, GM values were reported. Student's $t$-test was used to study differences of various pollutant concentrations between different organisms (Han et al., 1998).

\section{Results and discussion}

\subsection{Concentrations of metals and organochlorine pesticides in oysters}

Table 1 shows the GM metal concentrations in oysters collected from different coastal areas of Taiwan
Table 1

Geometric mean (GM) metal concentrations ( $\mu \mathrm{g} / \mathrm{g}$ dry wt) in oysters (Crassostrea gigas) collected from different coastal areas of Taiwan ${ }^{\mathrm{a}}$

\begin{tabular}{|c|c|c|c|c|}
\hline Location & $\mathrm{Cu}$ & $\mathrm{Zn}$ & $\mathrm{Cd}$ & As \\
\hline Hsiangshan ${ }^{\mathrm{b}}$ & $\begin{array}{c}1180 \\
(113-2806)\end{array}$ & $\begin{array}{c}1567 \\
(303-3593)\end{array}$ & $\begin{array}{c}1.10 \\
(0.167-2.93)\end{array}$ & $\begin{array}{c}12.1 \\
(7.15-17.6)\end{array}$ \\
\hline Shenkang ${ }^{\mathrm{b}}$ & $\begin{array}{c}203 \\
(32.6-560)\end{array}$ & $\begin{array}{c}704 \\
(139-1535)\end{array}$ & $\begin{array}{c}1.03 \\
(0.020-2.20)\end{array}$ & $\begin{array}{c}10.0 \\
(5.00-23.6)\end{array}$ \\
\hline Fupao $^{\text {b }}$ & $\begin{array}{c}183 \\
(37.65-922)\end{array}$ & $\begin{array}{c}1134 \\
(189-2828)\end{array}$ & $\begin{array}{c}0.983 \\
(0.100-1.85)\end{array}$ & $\begin{array}{c}11.3 \\
(5.15-31.7)\end{array}$ \\
\hline Wangkung ${ }^{\mathrm{b}}$ & $\begin{array}{c}378 \\
(60.3-948)\end{array}$ & $\begin{array}{c}983 \\
(263-1772)\end{array}$ & $\begin{array}{c}1.50 \\
(0.165-3.75)\end{array}$ & $\begin{array}{c}13.9 \\
(0.025-29.3)\end{array}$ \\
\hline Erliuchi estuary ${ }^{\mathrm{c}}$ & $\begin{array}{c}320 \\
(41.1-94.5)\end{array}$ & $\begin{array}{c}718 \\
(155-1685)\end{array}$ & $\begin{array}{c}1.75 \\
(1.10-4.25)\end{array}$ & $\begin{array}{c}13.0 \\
(2.30-34.9)\end{array}$ \\
\hline Fangyuan $^{\mathrm{b}}$ & $\begin{array}{c}417 \\
(35.7-988)\end{array}$ & $\begin{array}{c}820 \\
(155-1550)\end{array}$ & $\begin{array}{c}2.04 \\
(0.165-3.75)\end{array}$ & $\begin{array}{c}10.8 \\
(0.025-29.3)\end{array}$ \\
\hline Taishi $^{\mathrm{c}}$ & $\begin{array}{c}154 \\
(27.0-520)\end{array}$ & $\begin{array}{c}547 \\
(137-1145)\end{array}$ & $\begin{array}{c}1.20 \\
(0.550-2.40)\end{array}$ & $\begin{array}{c}17.1 \\
(7.05-19.4)\end{array}$ \\
\hline Putai $^{\mathrm{c}}$ & $\begin{array}{c}139 \\
(124-158)\end{array}$ & $\begin{array}{c}402 \\
(280-525)\end{array}$ & $\begin{array}{c}2.24 \\
(1.21-4.15)\end{array}$ & $\begin{array}{c}4.86 \\
(3.15-7.00)\end{array}$ \\
\hline Anpin $^{c}$ & $\begin{array}{c}545 \\
(378-1867)\end{array}$ & $\begin{array}{c}2545 \\
(574-3662)\end{array}$ & $\begin{array}{c}2.38 \\
(1.47-4.48)\end{array}$ & $\begin{array}{c}11.8 \\
(8.41-18.5)\end{array}$ \\
\hline Penghu Islands ${ }^{c}$ & $\begin{array}{c}11.4 \\
(8.20-15.7)\end{array}$ & $\begin{array}{c}220 \\
(187-259)\end{array}$ & $\begin{array}{c}1.49 \\
(1.45-1.52)\end{array}$ & $\begin{array}{c}6.35 \\
(6.25-6.45)\end{array}$ \\
\hline Machu Islands ${ }^{\mathrm{c}}$ & $\begin{array}{c}281 \\
(131-477)\end{array}$ & $\begin{array}{c}795 \\
(514-835)\end{array}$ & $\begin{array}{c}6.82 \\
(3.12-6.00)\end{array}$ & $\begin{array}{c}19.3 \\
(6.45-25.8)\end{array}$ \\
\hline Kimmen Islands ${ }^{\mathrm{c}}$ & $\begin{array}{c}172 \\
(89.0-349)\end{array}$ & $\begin{array}{c}748 \\
(605-1275)\end{array}$ & $\begin{array}{c}2.23 \\
(2.14-3.95)\end{array}$ & $\begin{array}{c}8.24 \\
(5.80-10.5)\end{array}$ \\
\hline Total GM & 229 & 783 & 1.76 & 10.8 \\
\hline
\end{tabular}

a Wet weight $\cong$ dry weight $\times 5$. All data are six to 56 determinations. Two extreme values in parentheses.

b Collected from 1991 to 1998.

c Collected from 1991 to 1996.

during 1991-98. Metal concentrations in oysters varied with different sampling locations. For instance, the highest $\mathrm{GM} \mathrm{Cu}$ and $\mathrm{Zn}$ concentrations of 1108 (range 113-2806) and 1567 (range 303-3593) $\mu \mathrm{g} / \mathrm{g}$ dry weight were obtained in oysters from the Hsiangshan coastal area, one of the most important oyster culture areas in Taiwan (Han et al., 1998). Cu and $\mathrm{Zn}$ pollution remains an acute problem because their concentrations in organisms, water and sediments have increased since 1986 (Han et al., 1998). There were low $\mathrm{Cu}(\mathrm{GM}=11.4$ $\mu \mathrm{g} / \mathrm{g}$ dry wt $)$ and $\mathrm{Zn}(\mathrm{GM}=220 \mu \mathrm{g} / \mathrm{g}$ dry wt $)$ concentrations in the oysters collected from the Penghu Islands (Table 1), probably because their location is far from pollution sources. However, the highest GM Cd and As concentrations of 6.82 and $19.3 \mu \mathrm{g} / \mathrm{g}$ dry weight were found in oysters from the Machu Islands which are very close to the Minjang estuary in the Fu-Chien province of southeastern China. On the other hand, the GM concentrations of As $(2.16 \mu \mathrm{g} / \mathrm{g}$ wet wt) in oysters of Taiwan is higher than those of legal limits for fish and shellfish products in some countries (Fig. 2).

In other words, the generally high $\mathrm{Cu}, \mathrm{Zn}, \mathrm{Cd}$ and As concentrations in oysters indicate that local and regional inputs of $\mathrm{Cu}, \mathrm{Zn}, \mathrm{Cd}$ and As are mainly in the 


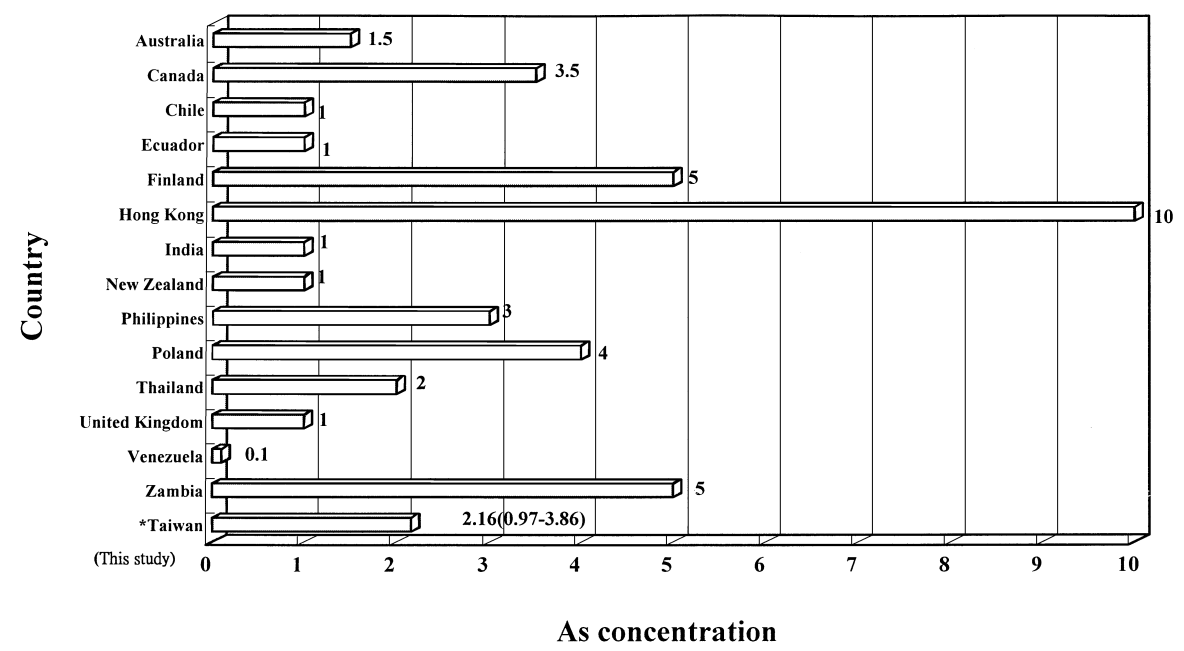

Fig. 2. Geometric mean $(\mathrm{GM})$ As concentrations ( $\mu \mathrm{g} / \mathrm{g}$ wet wt) in oysters of Taiwan compared to legal limits of As concentrations in fish and shellfish products from different countries.

Hsiangshan coastal area and Machu Islands, respectively (Hung et al., 1997; Tseng and Han, 1998). In general, bivalves are a hazard to health because they accumulate and concentrate toxins by continuously filter-feeding minute particles from water. Therefore, intake of high $\mathrm{Cd}$ and As concentrations through consumption of oysters collected from the Machu Islands could be dangerous, especially for some high-risk Machu residents.

Furthermore, Fig. 3 shows the average concentrations of organochlorine pesticides (such as $p, p^{\prime}$-DDE, $p, p^{\prime}$ DDD and $p, p^{\prime}$-DDT) in oysters collected from four different coasts of Taiwan. The $p, p^{\prime}$-DDE values range from not detectable in Penghu Islands' oysters to 164 ng/g dry weight in Machu Islands' oysters. The highest tDDT (sum of $p, p^{\prime}$-DDE, $p, p^{\prime}$-DDD and $p, p^{\prime}$-DDT) concentrations of 337 and $340 \mathrm{ng} / \mathrm{g}$ dry weight were found in oysters from Kimmen and Machu Islands, respectively. These concentrations are much higher than those reported by O'Connor (1996) that the GM concentrations of tDDT of $32 \mathrm{ng} / \mathrm{g}$ dry weight (range 20-46 ng/g dry wt) in the mollusks for sites sampled in at least 6 years from 1986 to 1993 . It is interesting that the relatively higher levels of As, Cd and tDDT are observed in oysters from Machu Islands than in those from other culture areas. The results could be explained that the extended use of organochlorine pesticides have resulted in the widespread distribution of these compounds in the oysters through the food chain in the environment. In spite of the use of tDDT having been prohibited for over 20 years, $p, p^{\prime}$-DDE showed the highest concentration among the pesticides tested in the oysters; hexachlorobenzene was present at low levels (Hung et al., 1997). From the human health viewpoint, the presence of organochlorine pesticides in oysters is of particular concern considering the high potential for accumulation of these compounds in human fatty tissue (Ling and Huang, 1995). In other words, organochlorine pesticides can cause a range of adverse effects on human health, such as cancer, genice effect, and

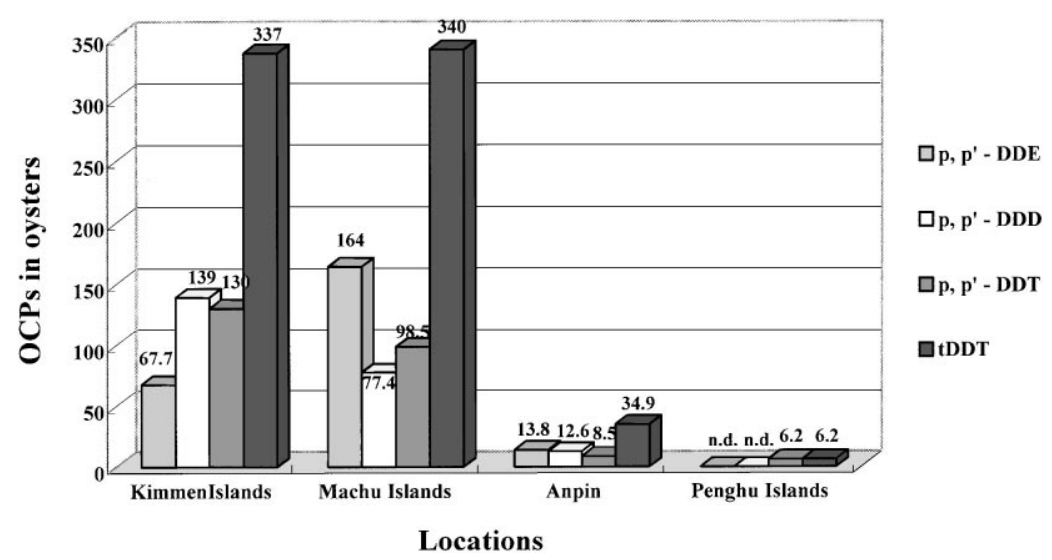

Fig. 3. Average concentrations (ng/g dry wt) of organochlorine pesticides (OCPs) in oysters (Crassostrea gigas) collected from different coasts of Taiwan. $\mathrm{tDDT}=p, p^{\prime}$-DDE $+p, p^{\prime}$-DDD $+p, p^{\prime}$-DDT; n.d., $p, p^{\prime}$-DDE and $p, p^{\prime}$-DDD $<6.0 \mathrm{ng} / \mathrm{g}$, respectively. 
acute and chronic injury to the nervous system (Hayes et al., 1971).

\subsection{Contaminant intake and health threat of consuming oysters}

In Taiwan, people's demand for protein and nutrients increases from consuming various seafood when their standard of living rises. Fish and shellfish are important food for supplying essential trace elements and certain vitamins; moreover, the polyunsaturated $n-3$ fatty acids in fatty fish species are biologically important and have been associated with a decreased risk for cardiovascular disease (Kromhout et al., 1985; Svensson et al., 1995). In Taiwan, of 11 major kinds of seafood, the oyster was not only in the top 10, but also the only shellfish in the top 11 (Han et al., 1994). Because oysters are one of the most popular seafoods in Taiwan, people consuming large amounts of contaminated oysters may have elevated concentrations of metals and organochlorine pesticides in their tissues compared to the general population.

In the questionnaire, the oyster consumers were divided into four groups: a slight-intake group $(<18.6 \mathrm{~g} /$ day), a moderate-intake group (18.6-56 g/day), a highintake group (65-130 g/day) and the highest-intake group (>139 g/day) (Fig. 4). Typical oyster consumption value is $<18.6 \mathrm{~g} / \mathrm{day}$, whereas 'extreme' values (for high consumers such as subsistence fishermen group) range to $139 \mathrm{~g} /$ day. In general, two types of hypothetical oyster consumption scenarios were identified and evaluated in this assessment (Copper et al., 1991). The first was to represent the maximum exposed individual (MEI), assumed to consume $139 \mathrm{~g} /$ day of oysters. The second type of consumption scenario was for typically general consumers (TGC) $(90.0 \%$ of residents) who were assumed to consume $18.6 \mathrm{~g} /$ day. We assume that all of the oysters consumed by local residents were

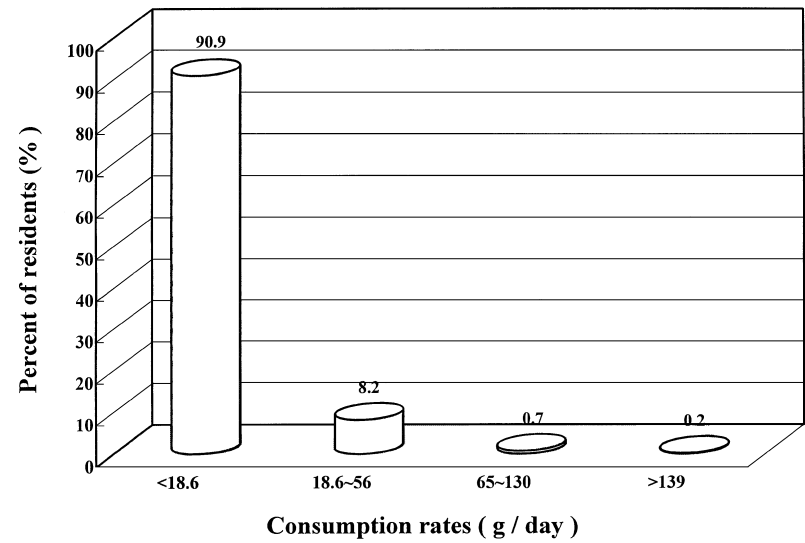

Fig. 4. The percentage of oyster consumption rates among residents of Taipei City, Taiwan.

cultured in the different areas. Table 2 shows the results of estimated THQs for metals caused by consuming oysters from different sampling locations. For calculating THQs of As, inorganic As used was 10\% of the total (Edmonds and Francesconi, 1993). Although most of the As in food appears to be organically bound, this form is substantially less toxic than inorganic As. US EPA considers the latter form to be carcinogenic by ingestion (Rodricks and Jackson, 1992). A THQ of 11.4 (based on $139 \mathrm{~g}$ oysters/day) for $\mathrm{Cu}$ caused by consuming oysters from the Hsiangshan area is higher than that from other areas (range 0.124-5.95). The highest average $\mathrm{Cu}$ intake from Hsiangshan's oysters for individuals is 11.4 times (i.e. $\mathrm{THQ}=11.4$ ) more than that of reference dose ( $40 \mu \mathrm{g} / \mathrm{kg} /$ day). However, the maximum THQ values for $\mathrm{Cd}$ and As caused by consuming oysters collected from the Machu Islands had THQs of 5.57 and 2.63 , respectively. Table 2 also shows that for maximally exposed individuals, $65.4 \%$ (34 out of 52 THQ) of THQs exceeded 1.0. In other words, one who has long-

Table 2

Various estimated target hazard quotients for metals caused by consuming oysters from different culture areas ${ }^{\mathrm{a}}$

\begin{tabular}{|c|c|c|c|c|c|c|c|c|}
\hline \multirow[t]{2}{*}{ Location } & \multicolumn{4}{|c|}{ Maximally exposed individuals } & \multicolumn{4}{|c|}{ Typically exposed individuals } \\
\hline & $\mathrm{Cu}$ & $\mathrm{Zn}$ & $\mathrm{Cd}$ & Inorganic As & $\mathrm{Cu}$ & $\mathrm{Zn}$ & $\mathrm{Cd}$ & Inorganic As \\
\hline Hsiangshan & 11.4 & 2.15 & 0.92 & 1.65 & 1.52 & 0.29 & 0.12 & 0.21 \\
\hline Shenkang & 1.35 & 0.70 & 0.62 & 1.42 & 0.18 & 0.09 & 0.08 & 0.18 \\
\hline Fupao & 2.62 & 1.32 & 0.56 & 1.50 & 0.35 & 0.18 & 0.07 & 0.19 \\
\hline Wangkung & 3.16 & 1.13 & 0.96 & 1.80 & 0.42 & 0.15 & 0.13 & 0.22 \\
\hline Erhjin Chi estuary & 3.28 & 0.98 & 1.43 & 1.77 & 0.44 & 0.13 & 0.19 & 0.22 \\
\hline Fangyuan & 3.76 & 0.95 & 1.19 & 1.17 & 0.50 & 0.13 & 0.16 & 0.15 \\
\hline Taishi & 1.58 & 0.75 & 0.98 & 2.33 & 0.21 & 0.10 & 0.13 & 0.29 \\
\hline Putai & 1.43 & 0.55 & 1.83 & 0.66 & 0.19 & 0.07 & 0.24 & 0.08 \\
\hline Anpin & 5.95 & 3.48 & 0.90 & 1.34 & 0.80 & 0.47 & 0.12 & 0.18 \\
\hline Tainan & 0.81 & 0.51 & 0.98 & 1.60 & 0.11 & 0.07 & 0.13 & 0.20 \\
\hline Penghu Islands & 0.124 & 0.30 & 1.22 & 0.87 & 0.02 & 0.04 & 0.16 & 0.11 \\
\hline Machu Islands & 2.88 & 1.09 & 5.57 & 2.63 & 0.39 & 0.15 & 0.74 & 0.33 \\
\hline Kimmen Islands & 1.77 & 1.02 & 1.82 & 1.12 & 0.24 & 0.14 & 0.24 & 0.14 \\
\hline
\end{tabular}

${ }^{\text {a }}$ Reference doses of 40, 300, 0.5 and $0.3 \mu \mathrm{g} / \mathrm{kg} /$ day for $\mathrm{Cu}, \mathrm{Zn}, \mathrm{Cd}$ and inorganic As, respectively (US EPA, 1998). 
time exposure to four metals through consumption of oysters will have potential health risks, especially for Machu Islands area. Gorell et al. (1997) reported and suggested that chronic exposures to $\mathrm{Cu}, \mathrm{Hg}, \mathrm{Zn}$ and $\mathrm{Pb}$, etc., were associated with Parkinson's disease and that they might act alone or together over time to help produce the disease. The highest THQ values are 3.48, 5.57 and 2.63 for $\mathrm{Zn}, \mathrm{Cd}$ and inorganic As for Anpin and the Machu Islands, respectively. Bhamra and Costa (1992) indicated that the shellfish such as oysters are major sources of dietary Cd. Overall, the total daily intake of $\mathrm{Cd}$ from shellfish is generally estimated to be less than $100 \mu \mathrm{g} /$ day (Bhamra and Costa, 1992), whereas in certain polluted areas (such as in the Machu Islands), the estimated value may be as high as $181 \mu \mathrm{g} /$ day. This value is higher than that of total daily intake of $\mathrm{Cd}(150$ $\mu \mathrm{g} /$ day) from shellfish in Japan (Kjellstrom, 1979). In other words, intake of high $\mathrm{Cu}, \mathrm{Zn}, \mathrm{Cd}$ and inorganic As concentrations through consumption of oysters collected from Hsiangshan, Apain and the Machu Islands could be dangerous, especially for some high-risk fishmen. Considering their toxicity, $\mathrm{Cd}$ and As contaminants should be controlled with priority in these areas. Generally, the results of THQs showed that if only the maximally exposed individuals were considered, the value of $65.4 \%$ for oyster was higher than 1.0 in comparison with reference dose. It is interesting that abnormally high THQs (100\% over 1.0$)$ for $\mathrm{Cu}$, $\mathrm{Zn}, \mathrm{Cd}$ and inorganic As are caused by consuming oysters from the Machu Islands and Kimmen Islands. On the whole, it is important that consumption of contaminated oysters increases the total exposure to inorganic $\mathrm{As}, \mathrm{Cu}$ and $\mathrm{Cd}$ considerably.

Potential human health risks associated with inorganic As uptake for various oysters were evaluated. Carcinogenic risks were estimated by multiplying the exposure estimate by the carcinogenic slope factor for ingested inorganic As, i.e. $1.50(\mathrm{mg} / \mathrm{kg} / \mathrm{day})^{-1}$ (US EPA, 1998). Table 3 shows the various estimated lifetime cancer risks (TR) for inorganic As caused by consuming oysters collected from different culture areas. These risks varied with culture area and consumption rate. All cancer risk estimates for inorganic As from consuming oysters were higher than $10^{-6}$ (range from $128 \times 10^{-6}$ to $509 \times 10^{-6}$ for maximally exposed individuals and range from $17.1 \times 10^{-6}$ to $68.0 \times 10^{-6}$ for typically exposed individuals, respectively); that is the risk of cancer benchmark often used by the US EPA as the lower end of the range of acceptable risk (Yost and Schoof, 1995). The highest risk estimate for inorganic As was $509 \times 10^{-6}$ for consumption of oysters by the Machu Islands' residents. Hung et al. (1998) indicated that total As levels in both sediments and oysters from the Machu Islands were consistently two to six times higher than those from the Hsiangshan coastal area of Taiwan. There is reason to believe that these sediments are a
Table 3

Various estimated lifetime cancer risks for inorganic As caused by consuming oysters collected from different culture areas

\begin{tabular}{lll}
\hline Location & \multicolumn{2}{l}{ Lifetime cancer risks } \\
\cline { 2 - 3 } & $\begin{array}{l}\text { Maximally exposed } \\
\text { individuals }\left(\times 10^{-4}\right)\end{array}$ & $\begin{array}{l}\text { Typically exposed } \\
\text { individuals }\left(\times 10^{-5}\right)\end{array}$ \\
\hline Hsiangshan & 3.19 & 4.27 \\
Shenkang & 2.74 & 3.67 \\
Fupao & 2.90 & 3.88 \\
Wangkung & 3.48 & 4.65 \\
Erliuchi estuary & 3.43 & 4.58 \\
Fangyuan & 2.25 & 3.01 \\
Taishi & 4.51 & 6.03 \\
Putai & 1.28 & 1.71 \\
Anpin & 2.58 & 3.46 \\
Penghu Islands & 1.67 & 2.24 \\
Machu Islands & 5.09 & 6.80 \\
Kimmen Islands & 2.17 & 2.91 \\
\hline
\end{tabular}

major source of exposure to the contaminants, but the sediments sampled are not the only source of exposure. It is also interesting to understand the relationship between high cancer risk of the Black-Foot Disease (BFD) patients and high lifetime cancer risk caused by consumption of oysters from the Putai (BFD) area. Chiou et al. (1995) reported that a high inorganic As intake from the well water of Putai had been associated with increased risks for cancer. In Taiwan, epidemiological studies of residents from fishing communities of the BFD area have shown multiple risk factors associated with As-induced skin cancer (Hsueh et al., 1995). Therefore, the Machu Islands' residents might be a suitable study base for epidemiological studies on the mortality and cancer mobility associated with dietary exposure to As and other metals.

As such, these assumptions are likely to overestimate exposure for many individuals. The MEI risk will exceed the highest risk threshold of $10^{-4}$ when oyster consumption is greater than $139 \mathrm{~g} /$ day. The risk $\left(10^{-6}\right)$ is slightly higher than that of consumption levels in excess of $18.6 \mathrm{~g} /$ day. These results suggest that 'average' consumers and 'extreme' consumers have different likelihoods of exceeding risk levels, an outcome that must be considered when evaluating the equitability of any proposed regulatory action (Lipton and Gillett, 1991). Based on the previous results (Han et al., 1998), there is a likelihood that some Taiwan residents consuming a certain amount of locally caught oysters may run the risk in between the amount used as maximum and typical in the calculation.

Table 4 shows the lifetime cancer risks for $p, p^{\prime}$-DDE, $p, p^{\prime}$-DDD and $p, p^{\prime}$-DDT caused by consuming oysters collected from four culture areas. The lifetime cancer risks of $19.0 \times 10^{-6}$ (based on $139 \mathrm{~g}$ oyster/day) for tDDT in oysters from the Machu Islands was higher than those from the Penghu Islands $\left(0.37 \times 10^{-6}\right)$. This 
Table 4

Various estimated lifetime cancer risks for organochlorine pesticides and inorganic As caused by consuming oysters collected from different culture areas

\begin{tabular}{|c|c|c|c|c|c|c|c|c|c|c|}
\hline \multirow[t]{3}{*}{ Location } & \multicolumn{10}{|c|}{ Lifetime cancer risks $\left(\times 10^{-6}\right)$} \\
\hline & \multicolumn{5}{|c|}{ Maximally exposed individuals } & \multicolumn{5}{|c|}{ Typically exposed individuals } \\
\hline & $p, p^{\prime}-\mathrm{DDE}$ & $p, p^{\prime}-\mathrm{DDD}$ & $p, p^{\prime}$-DDT & $\mathrm{tDDT}^{\mathrm{a}}$ & Total risk ${ }^{\mathrm{b}}$ & $p, p^{\prime}-\mathrm{DDE}$ & $p, p^{\prime}-\mathrm{DDD}$ & $p, p^{\prime}-\mathrm{DDT}$ & $\mathrm{tDDT}^{\mathrm{a}}$ & Total risk ${ }^{\mathrm{b}}$ \\
\hline Anpin & 0.825 & 0.532 & 0.508 & 1.870 & 260 & 0.110 & 0.071 & 0.068 & 0.250 & 34.9 \\
\hline Penghu Islands & $-^{\mathrm{c}}$ & - & 0.371 & 0.371 & 167 & - & - & 0.050 & 0.050 & 22.4 \\
\hline Machu Islands & 9.800 & 3.270 & 5.890 & 19.000 & 528 & 1.310 & 0.438 & 0.788 & 2.540 & 70.5 \\
\hline Kimmen Islands & 4.050 & 5.860 & 7.770 & 17.700 & 235 & 0.542 & 0.784 & 1.040 & 2.470 & 31.6 \\
\hline
\end{tabular}

a $\mathrm{tDDT}=p, p^{\prime}$-DDE $+p, p^{\prime}$-DDD $+p, p^{\prime}$-DDT.

$\mathrm{b}$ Total risk $=$ sum of risks for tDDT and inorganic As.

c - , not calculated.

result was 51.2 times higher than lifetime cancer risks for tDDT by consuming oysters from the Penghu Islands. It is possible that the higher lifetime cancer risks reflect organochlorine contamination in the Machu Islands. On the other hand, exposure to multiple toxicants may result in additive and/or interactive effects. Interactive effects may be synergistic or antagonistic. The US EPA set exposure standards which account for exposure to a class of toxicants in all media using an additive effects model (Hallenbeck, 1993). In other words, the total risk due to exposure to all members of a class of toxicants which appear in multiple media can be calculated (Hallenbeck, 1993). Therefore, the sum of lifetime cancer risks for tDDT and inorganic As had the highest risks (total risk $=528 \times 10^{-6}$ ) for consuming oysters from the Machu Islands. The total risk shows no difference variation $(p<0.05)$ between four different culture areas. Basically, the lifetime cancer risks for tDDT had lesser percentage contribution (range from 0.22 to $7.53 \%$ ) of total risks from four different oyster culture areas. In other words, the lifetime cancer risks for inorganic As may dominate as a total risk source for consuming oysters from various areas.

Fig. 5 shows estimates of lifetime cancer risk versus acceptable consumption rates of the Machu Islands' oysters. Where the risk level is low, such as $10^{-6}$ or lower, the exposure might be considered acceptable (US EPA, 1998). Regarding carcinogens of $10^{-6}$ for general population exposure, it is recommended that the US EPA unify the standard setting process by establishing an acceptable risk for all toxicants of a certain class and account for all media of exposure (Hallenbeck, 1993). However, where the risk is higher, various risk management decisions may have to be made. Using carcinogenic potency for inorganic As [CPSo $=1.5(\mathrm{mg} / \mathrm{kg} /$ day $)^{-1}$ ] and organochlorine pesticides $[$ CPSo $=0.34$, 0.24 and $0.34(\mathrm{mg} / \mathrm{kg} / \mathrm{day})^{-1}$ for $p, p^{\prime}$-DDE, $p, p^{\prime}$-DDD and $p, p^{\prime}$-DDT, respectively] (US EPA, 1998), a $10^{-6}$ upper limit on lifetime risk as the health protection standard would require maximum oyster consumption rates of approximately $0.26 \mathrm{~g} /$ day (the limit depends heavily on data and assumptions concerning oyster contamination concentrations) (Fig. 5). At the present time, cultured oysters in several areas of Taiwan contain total As and tDDT residues in the range of 4.86-19.3 $\mu \mathrm{g} / \mathrm{g}$ and $6.20-340 \mathrm{ng} / \mathrm{g}$ dry weight, respectively (Table 1). Clearly, it is important that the imposition of a 0.29 $\mu \mathrm{g} / \mathrm{g}$ dry weight (based on $139 \mathrm{~g}$ oysters/day) limit would mean the end of consuming the Machu Islands' cultured oysters until environmental levels of As decline to sufficiently low levels (Han et al., 1998). However, this tolerance level was chosen both to minimize health risk and to avoid an intolerable level of economic disruption in the affected industry (Hallenbeck, 1993).

These high consumption rates are likely to overestimate exposure for many consumers. For these reasons, a risk manager might weigh the risks associated with chemical contamination of fish and shellfish against the health benefits (e.g. decrease risk of heart disease) associated with consumption of fish and shellfish in place of meat (US EPA 1989). In general, risk

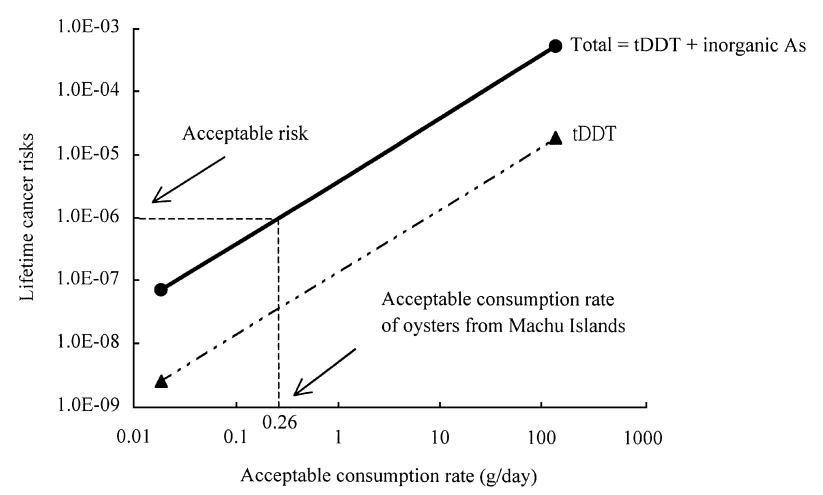

Fig. 5. Relationship between lifetime cancer risks for inorganic As and organochlorine pesticides, and acceptable consumption rates of Machu Islands' oysters (As and tDDT in oysters were $19.3 \mu \mathrm{g} / \mathrm{g}$ and $340 \mathrm{ng} / \mathrm{g}$ dry wt, respectively). $\mathrm{tDDT}=p, p^{\prime}$-DDE $+p, p^{\prime}$-DDD + $p, p^{\prime}$-DDT. 
managers should consider acceptable exceedence frequencies in addition to determining 'acceptable' risk levels. This level of acceptable uncertainty should be based on both the severity of the adverse effect and the size of the affected population (Lipton and Gillett, 1991).

The overall problem of metal contamination in seafood (especially for oysters) was more serious than was thought to be in such an industrialized and densely populated area. Some chemicals suspected of playing a role in human carcinogenesis were likely present but not overall analyzed for in the oysters of Hsiangshan and the Machu Islands. Furthermore, we also recommend limited consumption of oysters from polluted water (e.g. Erhjin Chi river and Hsiangshan area where the pollution sources have been identified; Han and Hung, 1990; Han et al., 1994, 1997) because most current health risks associated with seafood safety originate in the environment which should be dealt with by control of aquaculture sources or at the point of harvest (Han et al., 1994). In the long term, amelioration and eventual elimination of some hazards require strengthening and more effective application of control measures to prevent the disposal of human and industrial wastes into aquacultural estuarine and coastal environments. In addition, public health authorities should instruct consumers through public education to understand the potential and indirect risk of consuming oysters cultured in the polluted areas, and how to avoid the risk. At the same time, we hope that the government and the producers face the consequence of this problem and find a realistic way to resolve it.

\section{Acknowledgments}

We are grateful to three reviewers for constructive comments and suggestions. This study was supported by grants from the National Science Council, Republic of China (NSC-86-2621-B-038-001-Z, NSC-85-2621-B038-001-YZ and NSC-86-2815-C-038-014-B).

\section{References}

Asplund, L., Svensson, B.G., Nilsson, A., Eriksson, U., Jansson, B., Jensen, S., Wildeqvist, U., Skerving, S., 1994. PCB, $p, p^{\prime}$-DDT and $p, p^{\prime}$-DDE in human plasma related to fish consumption. Archives of Environmental Health 49, 477-486.

Bhamra, R.K., Costa, M., 1992. Trace elements aluminum, arsenic, cadmium, mercury and nickel. In: Lippmann, M. (Ed.), Environmental Toxicants - Human Exposure and their Health Effects. Van Nostrand Reinhold, New York, pp. 575-632.

Chen, C.Y., Ling, Y.C., 1994. Optimizing gas chromatographic separation and detection of polychlorinated biphenyls using electronic pressure programming and experimental design. Journal of High Resolution Chromatography and Chromatograhy Communications 17 (11), 784-791.
Chiou, H.Y., Hsueh, Y.M., Liaw, K.F., Horng, S.F., Chiang, M.H., Pu, Y.S., Lin, J.S.N., Huang, C.H., Chen, C.J., 1995. Incidence of internal cancers and ingested inorganic arsenic: a seven-year followup study in Taiwan. Cancer Research 55, 1296-1300.

Cooper, C.B., Doyle, M.E., Kipp, K., 1991. Risk of consumption of contaminated seafood: the Quincy Bay Case Study. Environmental Health Perspectives 90, 133-140.

Dewailly, E., Ryan, J.J., Laliberté, C., Bruneau, S., Weber, J.P., Gingras, S., Carrier, G., 1994. Exposure of remote maritime populations to coplanar PCBs. Environmental Health Perspectives 102 (Suppl.), 205-209.

Edmonds, J.S., Francesconi, K.A., 1993. Arsenic in seafoods: human health aspects and regulations. Marine Pollution Bulletin 26 (12), 665-674.

Gorell, J.M., Johnson, C.C., Rybicki, B.A., Peterson, E.L., Kortsha, G.X., Brown, G.G., Richardson, R.J., 1997. Occupational exposures to metals as risk factors for Parkinson's disease. Neurology 48, 650-658.

Hallenbeck, W.H., 1993. Quantitative Risk Assessment for Environmental and Occupational Health. Lewis, Chelsea, MI.

Han, B.C., Hung, T.C., 1990. Green oysters caused by copper pollution on the Taiwan coast. Environmental Pollution 65, 347-362.

Han, B.C., Jeng, W.L., Hung, T.C., Jeng, M.S., 1994. Copper intake and health threat by consuming seafood from copper-contaminated coastal environments in Taiwan. Environmental Toxicology and Chemistry 13, 775-780.

Han, B.C., Jeng, W.L., Hung, T.C., Wen, M.Y., 1996. Relationship between copper speciation in sediments and bioaccumulation by marine bivalves of Taiwan. Environmental Pollution 91, 35-39.

Han, B.C., Jeng, W.L., Jeng, M.S., Kao, L.T., Meng, P.J., Huang, Y.L., 1997. Rock-shells (Thais clavigera) as an indicator of As, Cu, and $\mathrm{Zn}$ contamination on the Putai coast of the Black-Foot Disease area in Taiwan. Archives of Environmental Contamination and Toxicology 32, 456-461.

Han, B.C., Jeng, W.L., Chen, R.Y., Fang, G.T., Hung, T.C., Tseng, R.J., 1998. Estimation of target hazard quotients and potential health risks for metals by consumption of seafood in Taiwan. Archives of Environmental Contamination and Toxicology 35, 711-720.

Hayes Jr., W.J., Dale, W.E., Pirkle, C.I., 1971. Evidence of the safety of long-term, high, oral doses of DDT for man. Archives of Environmental Health 22, 19-35.

Hsueh, Y.M., Cheng, G.S., Wu, M.M., Yu, H.S., Kuo, T.L., Chen, C.J., 1995. Multiple risk factors associated with arsenic-induced skin cancer: effects of chronic liver disease and malnutritional status. British Journal of Cancer 71, 109-114.

Hung, T.C., Kuo, C.Y., Chen, M.H., 1983. Mussel watch in Taiwan: (2) Seasonal bioaccumulative factors of heavy metals. Acta Oceanographica Taiwanica 12, 67-83.

Hung, T.C., Ling, Y.C., Jeng, W.L., Huang, C.C., Han, B.C., 1997. Marine environmental monitoring and QA/QC system in Taiwan. Journal of Chinese Environmental Protection Society 20, 69-90.

Hung, T.C., Ling, Y.C., Jeng, W.L., Huang, C.C., Han, B.C., 1998. International mussel watch program: Asia/Pacific phase-Taiwan region studies. National Science Council Monthly 26, 390-400.

Kjellstrom, T., 1979. Exposure and accumulation of cadmium in populations from Japan, the United States, and Sweden. Environmental Health Perspectives 28, 169-197.

Kromhout, D., Bosschieter, E.B., Lezenne Coulander, C., 1985. The inverse relation between fish consumption and 20-year mortality from coronary heart disease. New England Journal of Medicine 312, 1205-1209.

Ling, Y.C., Huang, I.P., 1995. Multiresidue-matrix solid-phase dispersion method for determining 16 organochlorine pesticides and polychlorinated biphenyls in fish. Chromatographia 40, 259-266.

Ling, Y.C., Liao, J.H., 1996. Matrix effect on supercritical fluid extraction of organochlorine pesticides from sulfur-containing soils. Journal of Chromatography 754A, 285-294. 
Ling, Y.C., Chang, M.Y., Huang, I.P., 1994. Matrix solid-phase dispersion extraction and gas chromatographic screening of polychlorinated biphenyls in fish. Journal of Chromatography 669A $(1 / 2), 119-124$.

Lipton, J., Gillett, J.W., 1991. Uncertainty in ocean-dumping health risks: influence of bioconcentration, commercial fish landings and seafood consumption. Environmental Toxicology and Chemistry 10, 967-976.

O'Connor, T.P., 1996. Trends in chemical concentrations in mussels and oysters collected along the US coast from 1986 to 1993. Marine Environmental Research 41, 183-200.

Rodricks, J.V., Jackson, B.A., 1992. Food constituents and contaminants. In: Lippmann, M. (Ed.), Environmental ToxicantsHuman Exposure and Their Health Effects. Van Nostrand Reinhold, New York, pp. 266-298.

Svensson, B.G., Nilsson, A., Josson, E., Schütz, A., Åkesson, B., Hagmar, L., 1995. Fish consumption and exposure to persistent organochlorine compounds, mercury, selenium and methylamines among Swedish fishermen. Scandinavia Journal of Work Environmental Health 21, 96-105.

Tseng, R.J., Han, B.C., 1998. From the Relationship Between Con- centration of Heavy Metals in Sediments and Oysters to Assess Aquaculture Environment on the West Coast of Taiwan (Special Publication). Council of Agriculture, Taipei, Taiwan, Republic of China.

UNEP, 1993. United National Environment Program: Environmental Data Report, 1993-1994. Blackwell Publishers, Oxford.

UNU, 1994. Report of the UNU-IOC Workshop on Asia/Pacific Mussel Watch: Monitoring, Research and Training, November 1821 1994, Bali, Indonesia.

US EPA, 1989. Guidance Manual for Assessing Human Health Risks from Chemically Contaminated Fish and Shellfish (EPA-503/889-002). US EPA Office of Marine and Estuarine Protection, Washington, DC.

US EPA, 1998. Risk-based Concentration Table. US EPA, Philadelphia, PA.

Yost, L.J., Schoof, R.A., 1995. Risk Assessment for Arsenic in a Marine Outfall, Including Consideration of Local Seafood Consumption Rates and Fractional Intake. Paper presented at the Second International Conference on Arsenic Exposure and Health Effects, Society for Environmental Geochemistry and Health, 12-14 June, San Diego, CA. 